\title{
Research and Analysis on Non-medical Approaches to Alleviate Fatigue
}

\author{
Xinjun Zhao \\ Department of Industrial Design \\ Northeastern University \\ Shenyang, China \\ xinjun_zhao@126.com.
}

\author{
Ying Zhong, Ying Zhao \\ Department of Industrial Design \\ Northeastern University \\ Shenyang, China
}

\begin{abstract}
With the fast development of society, it is a normal case for human to suffer fatigue, while the traditional approaches to alleviate fatigue cannot satisfy the requirements. The contemporarily commonly-used non-medical approaches to alleviate fatigue are summarized, which are related to human senses and work together with specific products to alleviate fatigue. By summarizing the non-medical ways to alleviate fatigue, a reference is provided for the product design of fatigue alleviation in the future and a basis in theory is built for studying more efficient ways to alleviate fatigue.
\end{abstract} design

Keywords-alleviate fatigue; non-medicalapproaches; product

\section{INTRODUCTION}

Fatigue results in kinds of chronic illnesses. Along with the development of society, the population of death from overworks keeps increasing over recent years. Also, it is not a rare case that long-time chronic fatigue leads to the sudden death. Aiming at alleviating fatigue, we have to figure out solutions as soon as possible [1].

For both traditional Chinese medicine and western medicine, in the early stage, the main approach to alleviate fatigue is based on medicine. With the development of fatigue research, people found that fatigue is not only restricted to physical fatigue. On the contrary, different kinds of fatigue require different alleviation approaches. In the current market, there are many products combined with physiotherapy, such as massage instruments and aromatherapy instruments etc.

\section{THERAPY BASED ON HUMAN SENSE}

\section{A. Therapy Based on Visual Perception}

Color can be perceived by human body through eyes, skin, and head bone. Every cell in human body can obtain energies through sunlight. Thus, the color energy can affect human body, emotion and spirit through cell absorption[2]. When the ancient Indian people practice Yoga, they could reach better training performance through the natural sunlight. The commonly used colors for therapy are listed in Table 2.1. The common therapies based visual perception are listed in Table 2.2.
TABLE 2.1 COLORS FOR THERAPY AND THE FUNCTIONS

\begin{tabular}{|l|l|}
\hline Color & \multicolumn{1}{|c|}{ Function } \\
\hline Blue & $\begin{array}{l}\text { Beneficial to insomnia and hypertension, reduce sensitivity } \\
\text { to pain. }\end{array}$ \\
\hline Green & $\begin{array}{l}\text { Relax tension, promote digestion, improve balance } \\
\text { capability, keep inner peace, and overcome syncope. }\end{array}$ \\
\hline Yellow & $\begin{array}{l}\text { Beneficial to cure constipation and enhance self-confidence, } \\
\text { stimulate nervous system and digestion system, improve } \\
\text { logic thinking. }\end{array}$ \\
\hline Purple & $\begin{array}{l}\text { Beneficial to alleviate addiction disorders and migraine, } \\
\text { improve motor nerves system, lymphatic system and the } \\
\text { cardiac system, keep potassium balance. }\end{array}$ \\
\hline $\begin{array}{l}\text { Cyan- } \\
\text { blue }\end{array}$ & $\begin{array}{l}\text { Beneficial for joint problems and varicose veins. } \\
\text { Orange }\end{array} \begin{array}{l}\text { Beneficial to keep vigor, induce appetite, help absorb } \\
\text { calcium, support recovery and keep healthy. }\end{array}$ \\
\hline Red & $\begin{array}{l}\text { Beneficial to overcome idleness and and improve sexual } \\
\text { desire, stimulate and excite nervous system, enhance } \\
\text { adrenaline and blood circulation. }\end{array}$ \\
\hline Red & \begin{tabular}{l} 
Beneficial to keep calmness and reduce pressure. \\
\hline
\end{tabular}
\end{tabular}

TABLE2.2 COMMON CHROMOTHERAPY

\begin{tabular}{|l|l|}
\hline \multicolumn{1}{|c|}{$\begin{array}{c}\text { Names of } \\
\text { Therapy }\end{array}$} & \multicolumn{1}{|c|}{ Introduction } \\
\hline Chromotherapy & $\begin{array}{l}|c| \\
\text { health and life style of patients the } \\
\text { chromotherapist exhibits scarves in different } \\
\text { colors, from which the patient select scarves in } \\
\text { four colors. Then, the chromotherapist starts } \\
\text { therapy according to the color selections by } \\
\text { deploying color lights against different positions } \\
\text { of the patient body. }\end{array}$ \\
\hline $\begin{array}{l}\text { Sensory } \\
\text { coordination } \\
\text { relaxation }\end{array}$ & $\begin{array}{l}\text { Combine color, light, and music into special } \\
\text { products that help users to lower pressure and } \\
\text { relax [3]. }\end{array}$ \\
\hline Color Yoga & $\begin{array}{l}\text { The Yoga teacher shines the color lights on the } \\
\text { back of students to improve the practice } \\
\text { performance. }\end{array}$ \\
\hline Color recuperation & $\begin{array}{l}\text { Deploying different colors in rooms to let } \\
\text { customers recuperate. }\end{array}$ \\
\hline Color diet therapy & $\begin{array}{l}\text { Use the food with pigments, based on the } \\
\text { research that proves the pigments in foods are } \\
\text { beneficial for health [4]. }\end{array}$ \\
\hline Red light therapy & $\begin{array}{l}\text { Red light is helpful to alleviate fatigue related to } \\
\text { neurasthenia, depression, as well as improving } \\
\text { sleepiness and curing hurt, skin disease, blood } \\
\text { disease, bone disease, and kinds of pain. [5] }\end{array}$ \\
\hline
\end{tabular}




\section{B. Therapy Based on Hearing Perception}

The most commonly-used therapy is music therapy. While both eastern and western medicine have deep understanding and research on music therapy. The common music therapy approaches [6] are summarized in Figure 2.1. The detail of several music therapies is listed in Table 2.3.

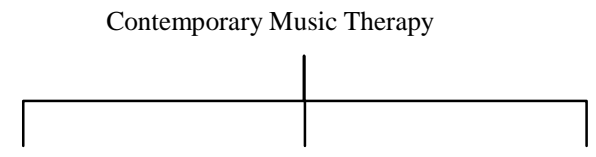

Receptive Treatment Active Music Treatment Mixed Music Treatment

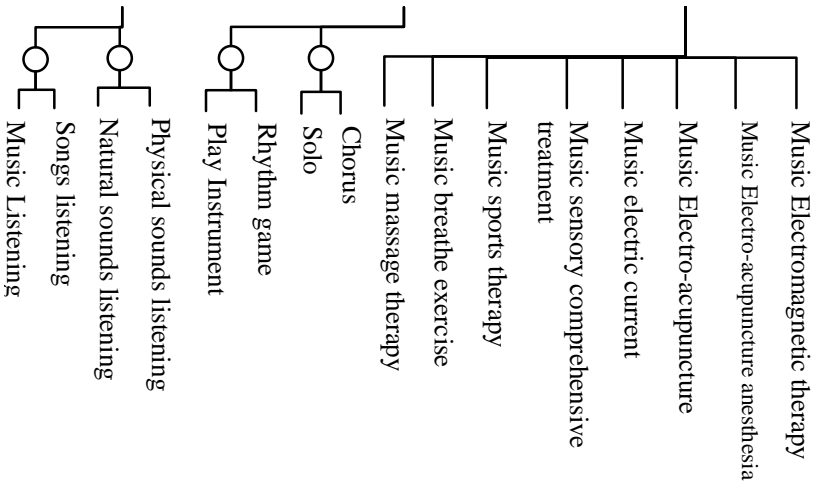

FIGURE 2.1 CLASSIFICATION OF CONTEMPORARY MUSIC THERAPY

TABLE2.3 INTRODUCTION OF MUSIC THERAPY

\begin{tabular}{|l|l|}
\hline \multicolumn{1}{|c|}{$\begin{array}{c}\text { Names of } \\
\text { Therapy }\end{array}$} & \multicolumn{1}{c|}{ Introduction } \\
\hline $\begin{array}{l}\text { Pure music } \\
\text { therapy }\end{array}$ & $\begin{array}{l}\text { Select music based on the advisory of therapist to } \\
\text { provide a relaxing environment, adjust emotion to } \\
\text { reach the goal of cure. }\end{array}$ \\
\hline $\begin{array}{l}\text { Music Electro- } \\
\text { acupuncture }\end{array}$ & $\begin{array}{l}\text { Originating from China, it combines the traditional } \\
\text { acupuncture, electro-acupuncture, and music therapy. }\end{array}$ \\
\hline $\begin{array}{l}\text { Music electric } \\
\text { current } \\
\text { therapy }\end{array}$ & $\begin{array}{l}\text { Combining with meridian and music therapy [7], } \\
\text { make use of music electric current instrument to } \\
\text { convert music to synchronized low and middle } \\
\text { frequency current that travels in the human body to } \\
\text { reach the goal of cure. }\end{array}$ \\
\hline $\begin{array}{l}\text { Other } \\
\text { therapies }\end{array}$ & $\begin{array}{l}\text { relevant activities that are beyond the pure music } \\
\text { listening, such as listening, singing, instrument } \\
\text { playing, dancing, and painting etc. Also, the music } \\
\text { therapy complimented with other kinds of therapies is } \\
\text { proven effective to alleviate fatigue [8]. }\end{array}$ \\
\hline
\end{tabular}

\section{Therapy Based on Olfactory Perception}

The common approaches of aromatherapy include smelling perfume, massage, bath, while Compendium of MateriaMedica also introduces rubbing, plaster, blowing, mouthwash etc[9]. Table 2.4 lists common approaches of aromatherapy.

Aromatherapy requires different kinds of spices including different kinds of plants and the different parts of plants [10]. Table 2.5 shows the common spices and their functions.
TABLE2.4 COMMON APPROACHES OF AROMATHERAPY

\begin{tabular}{|l|l|}
\hline \multicolumn{1}{|c|}{$\begin{array}{c}\text { Names of } \\
\text { Therapy }\end{array}$} & \multicolumn{1}{c|}{ Introduction } \\
\hline $\begin{array}{l}\text { Aromatic dry } \\
\text { sauna }\end{array}$ & $\begin{array}{l}\text { Combining spices and Finnish bath, reach the goal of } \\
\text { cure by steam. }\end{array}$ \\
\hline $\begin{array}{l}\text { Aromatic } \\
\text { massage }\end{array}$ & $\begin{array}{l}\text { The whole body massage with aromatic oils is a great } \\
\text { way to alleviate fatigue. }\end{array}$ \\
\hline Fumigation & $\begin{array}{l}\text { Add aromatic oils and water to fragrance lamp and } \\
\text { have the oil fumigation through ultra-wave or } \\
\text { heating. }\end{array}$ \\
\hline $\begin{array}{l}\text { Aromatic } \\
\text { gardens }\end{array}$ & $\begin{array}{l}\text { Applying aromatic plants to the environmental } \\
\text { design, build the eco-lawn to reach the goal of } \\
\text { aromatherapy. }\end{array}$ \\
\hline $\begin{array}{l}\text { SPA music } \\
\text { therapy }\end{array}$ & $\begin{array}{l}\text { The music therapy complemented with SPA creates } \\
\text { recovery spaces. }\end{array}$ \\
\hline
\end{tabular}

TABLE2.5 THE COMMON SPICES AND THE FUNCTIONS

\begin{tabular}{|c|c|}
\hline $\begin{array}{l}\text { Names of } \\
\text { Therapy }\end{array}$ & Introduction \\
\hline $\begin{array}{l}\text { Lavender } \\
\text { (flowers) }\end{array}$ & $\begin{array}{l}\text { Prevent colds and virus infection; alleviate fatigue } \\
\text { and tensions, relax muscles, benefit sleep, and } \\
\text { prevent aging. }\end{array}$ \\
\hline $\begin{array}{l}\text { Eucalyptus } \\
\text { (leaf) }\end{array}$ & $\begin{array}{l}\text { Disinfect, sterilize, improve air quality, increase } \\
\text { immunity; Fresh mind, relieve fever, and benefit } \\
\text { formation of new skin tissue. }\end{array}$ \\
\hline $\begin{array}{l}\text { Rosemary } \\
\text { (flower top) }\end{array}$ & $\begin{array}{l}\text { Refresh spirit, relieve pain, help blood circulation, } \\
\text { sterilize andantiphlogosis. (suitable to students and } \\
\text { those overworked). }\end{array}$ \\
\hline Tea (leaves) & $\begin{array}{l}\text { Sterilize, increase immunity, keep inner peace, } \\
\text { disinfect, and improve resistance to bug bites. }\end{array}$ \\
\hline Lemon (peel) & $\begin{array}{l}\text { Promote metabolism, immunity, keep calm, stabilize } \\
\text { emotions, improve confidence, sterilize, prevent gout, } \\
\text { fresh air, and keep minds fresh. }\end{array}$ \\
\hline $\begin{array}{l}\text { Peppermint } \\
\text { (leaf) }\end{array}$ & $\begin{array}{l}\text { Excite nervous systems, disinfect, cure colds and } \\
\text { bronchitis, relieve summer heat and winter cold, } \\
\text { alleviate tension and ignite vigor. }\end{array}$ \\
\hline Oran & $\begin{array}{l}\text { Cure cough and colds, promote blood circulation, } \\
\text { improve spirit, keep inner peace, and ignite } \\
\text { excitement. }\end{array}$ \\
\hline $\begin{array}{l}\text { Basil (leaves, } \\
\text { pet-als) }\end{array}$ & $\begin{array}{l}\text { Adjust digestion system, promote blood circulation, } \\
\text { improve energy, keep focus, and enhance memory, } \\
\text { sterilize, expectorant. }\end{array}$ \\
\hline Cedar (wood) & $\begin{array}{l}\text { then the endocrine, nervous system, and } \\
\text { e, expectorant and meditation. }\end{array}$ \\
\hline $\begin{array}{l}\text { Cypress } \\
\text { (leaves) }\end{array}$ & $\begin{array}{l}\text { Help blood circulation, vasoconstrictor, ease asthma, } \\
\text { cold, cough, bronchitis, refresh and calm, relieve } \\
\text { tension and pressure. }\end{array}$ \\
\hline $\begin{array}{l}\text { Grapefruit } \\
\text { (peel) }\end{array}$ & $\begin{array}{l}\text { Clam, relieve pressure, rid the inside water, strength } \\
\text { liver, diuretic, lose weight, refresh mind, refresh air, } \\
\text { and diminish smoking stink. }\end{array}$ \\
\hline $\begin{array}{l}\text { Eland (trees, } \\
\text { flow-ers) }\end{array}$ & $\begin{array}{l}\text { Calm, anti-depression, relax, alleviate tension, feel } \\
\text { comfort and euphoria. }\end{array}$ \\
\hline $\begin{array}{l}\text { Geranium } \\
\text { (flowers, } \\
\text { leaves) }\end{array}$ & $\begin{array}{l}\text { Nourish, clean, harmony, anti-depression, anti- } \\
\text { anxiety, strengthen immunity, prevent sore throat, } \\
\text { prevent cold, nervous pain, diuretic, and repellent. }\end{array}$ \\
\hline $\begin{array}{l}\text { Bergan } \\
\text { (peel) }\end{array}$ & $\begin{array}{l}\text { Anti-fever, disinfects, prevent bronchitis, cystitis, } \\
\text { indigestion, eliminate fear and tension, keep calm, } \\
\text { improve memory, improve migraine. }\end{array}$ \\
\hline
\end{tabular}

\section{ThERAPY BASED ON NEW PERSPECTIVE}

\section{A. Cat Snore Therapy}

Jean-Yves Gauchet, a veterinary, is the first to introduce "snore therapy". He invited volunteer to participate in the experiment, in which the cure function of cat snore as treatment was further examined. The experiment results show that the cat snore makes participants feel comfortable, peaceful, and help fall in sleep. According to the existing research, the snore of cat 
has the specific frequency that is beneficial to alleviate fatigue. When listening to the soft music, the human brain produces Dopamine, also called "happiness hormone", which have clear relationship with the alleviation of central nervous system fatigue.

\section{B. System of Healing Culture}

System of healing in Japan is directly translated to "spirit alleviation". Healing doesn't only mean curing physical hurts, but also focus on the sentiment in psychology. The system of healing culture consists of music, movie, book, product, and experience that give treatments to persons from multiple perspectives. The Japanese society is well-known for the great pressure that is recently aggravated by the natural disasters, such as earthquake and typhoon etc. As a typical example, the psychological problems after the earthquake bring the great challenge to Japanese and also provide a good opportunity for the system of healing culture to thrive, since it plays an important role on fatigue alleviation.

\section{Hug-Like Vest}

The recent research found that the regular hug reduces the chance to have heart disease, conquer pressure and fatigue, improve immunity, resist inflammation, and relieve depression. Squease, a UK company, invented a magic inflatable vest that makes people have the feeling of hug-like. It is applicable for autism to keep calm under pressure.

\section{Wooden Space}

As a style of space, the wooden space not only lets patients feel the sense of returning nature, but the other properties of wood have different effects on the person in the space.

Due to kinds of volatile oils in the woods, the forest-like perfume gives people the impression of freshness, simply and elegance. The research proves that when people feel fatigue during the long time working, appropriate amount of fresh perfume makes the head clear and reduces the chance to do things wrong. The elegant feeling when touching woods affect both human body and spirit. Also, woods have special sound property. It is a long history to use woods to decorate interior space. The sound, when people walking through wooden floor or things falling on the wooden floor, distinguishes from the sounds occurred on stone, rubber, or concrete etc.

Albeit the function of wooden space as treatment still needs more proof, the properties of woods and the idea of wooden space are really helpful for the research on fatigue alleviation.

\section{CONCLUSIONS}

Currently, there are a lot of researches on human fatigue, especially human chronic fatigue syndrome, but there are great limitations to fully solve the problem of human fatigue in medicine.

The paper firstly studies the novel therapies based on multiple human senses, which starts from the human senses, then builds the cure space by adjusting the environmental factors. It is proven by practice that these therapies are beneficial to alleviate fatigue with few side-effects.
In addition, the introductions of new perspective therapies offer creative ideas and means to alleviate fatigue, although the treatment applications of these therapies are quite limited. Only if designers take part in the research on alleviating fatigue, the treatment of alleviating fatigue becomes more complete and general. Thus, the trend of worsening situation of human fatigue can be controlled.

\section{REFERENCES}

[1] Daming Tang.Responsibilities of Industrial Design on Alleviating Fatigue. Science and Technology Consulting Herald, 2012, No. 15.

[2] http://club.dayoo.com/view-15613795-1-1.html.

[3] http://www.hellohiheart.com/article/118.html.

[4] http://www.99.com.cn/zhongliu/zrlf/109776_3.htm.

[5] DanbingJia, Naimin Li. Fatigue Science [M]. Beijing: Xueyuan Press, 2009.

[6] Junyin Cao. Experimental Research of Perfume Therapy on Training Mouse to Prevent Fatigue[D]. Xian : Shaanxi Normal University, 2008.

[7] Jing Zhang, SishengTian. Discussions of Chinese Medicine Theory on Chinese Music Therapy[J]. China Journal of Traditional Chinese Medicine and Pharmacy. 2011, No. 05.

[8] pavlicevic, Lin Su. Music therapy theory and Practice [M] . Beijing : World Publication Company. 2006.

[9] http://baike.baidu.com/view/1218929.htm?reforce=\%B7\%BC\%CF\%E3 $\% \mathrm{C} 1 \% \mathrm{C} 6 \% \mathrm{~B} 7 \%$ A $8 \&$ hold=synstd.

[10] Yongjie Li, XuguangGao, Dexin Wang. PsychologicalProperties Research of Chronic Fatigue Syndrome[J] . Chinese Medical Journal. 2005, No. 41.

[11] Linwen He. Research on Detection of the Driver Fatigue Based on the Fusion of Multiple Features [D], Changsha : Central South University of Forestry and Technology, 2009.

[12] http://new.060s.com/article/2011/12/14/508900.htm.

[13] http://news.21cn.com/luntan/liantang/2007/10/10/3712804.shtml. 